\title{
Effects of commercial layer feed supplementation on haematological and reproductive parameters of indigenous duck in rural area
}

\author{
Akter $\mathrm{F}^{1^{*}}$, Howlader MMR ${ }^{1}$, Hossain $\mathrm{MK}^{2}$, Hasan MMI ${ }^{1}$, Islam $\mathrm{S}^{1}$, Begum $\mathrm{S}^{1}$ \\ ${ }^{1}$ Department of Physiology, Sylhet Agricultural University, Sylhet-3100, Bangladesh. \\ ${ }^{2}$ Department of Surgery and Theriogenology, Sylhet Agricultural University, Sylhet-3100, Bangladesh.
}

[Received: May 28, 2015; Accepted: June 3, 2015]

\begin{abstract}
This study was carried out to evaluate the effects of supplementation of commercial layer feed on body weight, egg production and haematological profile of the laying ducks rearing under the rural condition of Bangladesh. Twenty indigenous ducks (Khaki Campbell $\mathrm{x}$ Local duck) of 24 weeks old was selected from a farm and randomly divided into four equal groups ( $n=5)$ and numbered as group $T_{0}, T_{1}, T_{2} \&$ $T_{3}$. The different amount of feed was supplied into four groups for three months. The all four groups $\left(T_{0}, T_{1}, T_{2}\right.$ and $\left.T_{3}\right)$ were fed with routine feeding in scavenging condition. But $\mathrm{T}_{1}$ group supplemented with $120 \mathrm{gm}, \mathrm{T}_{2}$ group $60 \mathrm{gm}$ and $\mathrm{T}_{3}$ group $30 \mathrm{gm}$ of commercial feed. Significant differences were found in both egg production and haematological profile of ducks in compared to control group. Egg production was significantly $(\mathrm{P}<0.01)$ higher in $\mathrm{T}_{1}$ group compared to other groups. During the study the body weight gain were shown the same pattern being significantly $(P<0.05)$ higher in $T_{1}$ group compared to $T_{0}, T_{2}$ and $T_{3}$ groups. On the other hand, the values of total erythrocyte count (TEC), total leukocyte count (TLC), haemoglobin content $(\mathrm{Hb})$ and packed cell volume (PCV) increased significantly $(\mathrm{P}<0.05)$ in the groups of $T_{1}$ and $T_{2}$ compared to the control group (T0). But the value of $\mathrm{MCV}, \mathrm{MCH}$ and $\mathrm{MCHC}$ of $\mathrm{T}_{1}, \mathrm{~T}_{2} \& \mathrm{~T}_{3}$ groups decreased significantly $(\mathrm{P}<0.05)$ than that of the control group. Results of the present study revealed that the amount of supplementation of commercial layer feeds was very important for improving the haematological profile and egg production of ducks. So, the additional commercial layer feed supplementation may be beneficial for duck farming.
\end{abstract}

Key words: Duck, feeds, haematological profile, body weight, egg production.

\section{INTRODUCTION}

Poultry sector developed tremendously in the last two decades in Bangladesh. Now a days, thousands of small and large scale of poultry farm is available in our country. Among all the industrial sectors, on which the economic strength of Bangladesh depends, poultry sector is one of the most rising, vital and prominent one. Poultry sector is a very flourishing and promising arena of the country for her economic development.

Poultry keeping is an integral part of the rural farming system that provides family income for the small, marginal and landless poor. Among poultry populations there are about 39.08 million ducks in Bangladesh [1] with an average of 4.16 ducks per household [2], of which 95 per cent are of indigenous. It was found that 78 percent of egg and 86 percent of poultry meat is produced by the smallholders under scavenging condition [3]. Rearing of ducks gives maximum return with minimum cost. Ducks are traditionally raised under scavenging by the smallholders in coastal and lowlying areas, with little or no feed supplementation. Duck production in the Haor region (Habiganj) of Bangladesh provides self-employment for landless and small farmers. There is a great potentiality of improving the productivity of ducks in coastal and Haors areas through supplementary feeding. Ducks, being an important poultry species, can contribute efficiently in increasing egg and meat production than chicken in the low lying areas in Habiganj district. From selling ducks and eggs most of the households earn huge money per month. Agricultural resources for scavenging duck rearing system is considered to have potential both for poverty alleviation and food production, especially for the rural poor women.

Analysis of normal hematological parameters of duck is very much essential in diagnosing the various pathological and metabolic disorders. It can be used as a diagnostic tool in order to assess the health status of an individual and/ or a flock [4]. Haematological changes are routinely used to determine various status of the body and to determine stresses due to environmental, nutritional and / or pathological factors. Because of these facts, during the recent decades the avian physiology is found to be of great importance to the scientists, researchers and veterinarians as well as poultry growers.

Haematological values of duck are influenced by age, sex, breed, climate, geographical location, season, day length, time of day, nutritional status, life habit of species, present status of individual and such other physiological factors [5].Therefore, the present study was designed to assess the egg production potential and haematological parameters of native duck under scavenging conditions with different level of feed supplementation. 


\section{MATERIALS AND METHODS}

This study was conducted at Ajmiriganj Upazilla of Habigonj district in Sylhet division. Twenty laying indigenous ducks ( Khaki Campbell X Local duck) of 24 weeks old was collected from a farm and randomly divided them into four equal groups $(n=5)$ and numbered them as group $\mathrm{T}_{0}, \mathrm{~T}_{1}, \mathrm{~T}_{2} \& \mathrm{~T}_{3}$. Four different level of feed supplementation were considered for four different treatments. The treatment was continued until the peak production reached that is 34 weeks of age. So the rearing period of these ducks was 3 months (March-June) and observed the result for this period. The laboratory analysis of the experiment was done in the District Veterinary Hospital, Habiganj, Sylhet and Horekrisno Diagnostic Center, Ajmiriganj, Habiganj. The following methodology was adopted for performing the experiment.

\section{Experimental Ducks}

The research work was conducted using twenty indigenous ducks of 24 weeks old. First; all ducks were treated with anthelmintic piperazine citrate, doses of $1 \mathrm{gm}$ for 7 ducks. After seven days of deworming, all ducks were vaccinated against duck plague virus disease. The ducks were grouped randomly as $T_{1}, T_{2}, T_{3}$ and $T_{0}$. Each group comprised of five ducks and was allocated to different respective treatment. The initial body weights of each duck were recorded. The egg production, body condition, body weight and haematological parameters were also recorded on post treatment.

\section{Marking of ducks}

Each ducks of every group were leg banded with 4 different colour, $\mathrm{T}_{1}$ was pink banded, $\mathrm{T}_{2}$ was red banded, $\mathrm{T}_{3}$ was black banded and $\mathrm{T}_{0}$ was green banded. Except the $\mathrm{T}_{1}$, the other three treatments were colour sprayed on their head similar to their leg band to identify the particular eggs from particular duck. Four coloured signature pen similar to the leg band colour were used to give mark in the egg.

\section{Feeding Management}

We had collected commercial layer feed from Nourish Feed Company for treating the experimental duck. Four different level of feed supplementation were considered as four different treatments. Treatment-1 $\left(\mathrm{T}_{1}\right)$ was supplementary feed (120 g) with intensive feeding condition, Treatment-2 $\left(\mathrm{T}_{2}\right)$ was $60 \mathrm{~g}$ of feed with scavenging feeding condition, and Treatment-3 $\left(\mathrm{T}_{3}\right)$ was $30 \mathrm{~g}$ of feed with scavenging feeding condition and Treatment- $4\left(\mathrm{~T}_{0}\right)$ was fully scavenging without additional feed. Daily feed supply was weighed into polythene bags with $120 \mathrm{~g}, 60 \mathrm{~g}$ and $30 \mathrm{~g}$. Then the packets of feed were distributed among the group. In the early morning when the birds were taken from night shelter to the pens, half of the feed from 120 and $60 \mathrm{~g}$ were given to the $T_{1}$ and $T_{2}$, but in $T_{3}$ the whole amount $(30 \mathrm{~g})$ were given to the bird. Rest of the feed from $\mathrm{T}_{1}$ and $\mathrm{T}_{2}$ was given at afternoon $(2 \mathrm{pm})$. During the time of feeding the door of $T_{2}$ and $T_{3}$ were closed to make sure that no feed waste was in the feeder.

\section{Blood Collection and haematological studies}

Blood was collected aseptically with sterile syringe and needle either from heart or from the wing vein of four different groups of birds. Immediately after collection, blood was transferred to sterile test tube containing anticoagulant (EDTA- .2 $\mathrm{mg} / \mathrm{ml}$ of blood). The hematological studies were performed within five hours after collection of blood by method of Lamberd and Rothstein [6]. Haematological studies were total erythrocyte count (TEC), total leukocyte count (TLC), estimation of hemoglobin $(\mathrm{Hb})$, determination of packed cell volume(PCV), determination of erythrocyte sedimentation rate (ESR), mean corpuscular volume (MCV), mean corpuscular hemoglobin (MCH) and mean corpuscular hemoglobin concentration (MCHC).

\section{Statistical Analysis:}

The obtained results were statistically analyzed using the standard computerized procedure Microsoft Excel-2010 for determination of mean, standard deviation, level of significance, standard error.

\section{RESULTS AND DISCUSSIONS}

The present research work was conducted to assess the efficiency of level of feed supplementation to indigenous duck under rural condition of Bangladesh (scavenging) in order to increase egg production and hematologic values. The results of present research work were stated and discussed under the following headings to investigate the hematological parameters and reproductive performance of duck in rural condition.

Effects of supplementation of commercial layer feed on Body weight 
The initial body weight of each groups were found approximately same (Table 1). At the end of experiment, the body weight of $\mathrm{T}_{0}, \mathrm{~T}_{1}, \mathrm{~T}_{2}$ and $\mathrm{T}_{3}$ groups were $1.40 \mathrm{~kg}, 2.24 \mathrm{~kg}, 2.16$ and $1.57 \mathrm{~kg}$, respectively (Table 1). Body weight gain was significantly different $(\mathrm{P}<0.05)$ between the treatments at the end of the experiment. The body weight gain of $\mathrm{T}_{1}$ was significantly $(\mathrm{P}<0.05)$ increased compared to other groups $\left(T_{0}, T_{2}\right.$ and $\left.T_{3}\right)$. The additional feed supplementation may increase in the above study. Irrespective of breeds, Islam et al.[8] also reported that the highest hen housed egg production was achieved by $70 \%$ supplementation followed by $50 \%$ and $30 \%$ supplementary feeding respectively. In the present study the $60 \mathrm{~g}, 30 \mathrm{~g}$ and 0 $\mathrm{g}$ feed supplementation is equivalent to $50 \%, 25 \%$ and $0 \%$, showing that $60 \mathrm{~g}$ gave significantly more egg than $30 \mathrm{~g}$ and $0 \mathrm{~g}$ being in agreement with Islam et al., [9].

Effects of supplementation of commercial layer

Table 1. Effects of commercial layer feed on physical condition and body weight (Mean $\pm \mathrm{SE})$ of experimental ducks

\begin{tabular}{|c|c|c|c|c|c|c|c|c|}
\hline \multirow[t]{2}{*}{ Parameters } & \multicolumn{2}{|c|}{ Group To } & \multicolumn{2}{|c|}{ Group $_{1}$} & \multicolumn{2}{|c|}{ Group $_{2}$} & \multicolumn{2}{|c|}{ GroupT $_{3}$} \\
\hline & $\begin{array}{l}\text { Initial } \\
\text { body wt. } \\
\text { (Mean } \pm \\
\text { SE) }\end{array}$ & $\begin{array}{l}\text { Final } \\
\text { body } \\
\text { wt. } \\
\text { (Mean } \pm S \\
\text { E) }\end{array}$ & $\begin{array}{l}\text { Initial } \\
\text { body wt. } \\
\text { (Mean } \pm \\
\text { SE) }\end{array}$ & $\begin{array}{l}\text { Final } \\
\text { body wt. } \\
\text { (Mean } \pm S \\
\text { E) }\end{array}$ & $\begin{array}{l}\text { Initial } \\
\text { body wt. } \\
\text { (Mean } \pm \\
\text { SE) }\end{array}$ & $\begin{array}{l}\text { Finalbod } \\
\text { ywt.(Mea } \\
n \pm S E)\end{array}$ & $\begin{array}{l}\text { Initial } \\
\text { body } \\
\text { wt. } \\
\text { (Mean } \\
\pm \text { SE) }\end{array}$ & $\begin{array}{l}\text { Finalbod } \\
\text { y.wt } \\
\text { (Mean } \pm S \\
\text { E) }\end{array}$ \\
\hline Feather & Rough & $\begin{array}{l}\text { Less } \\
\text { shiny }\end{array}$ & Rough & $\begin{array}{l}\text { Smooth } \\
\text { \& shiny }\end{array}$ & Rough & $\begin{array}{l}\text { Smooth } \\
\text { \& shiny }\end{array}$ & $\begin{array}{l}\text { Rou } \\
\text { gh }\end{array}$ & Smooth \\
\hline $\begin{array}{l}\text { Body wt. } \\
(\mathrm{kg})\end{array}$ & $\begin{array}{l}1.34 \pm 0.0 \\
3\end{array}$ & $\begin{array}{l}1.40 \pm 0.0 \\
5\end{array}$ & $\begin{array}{l}1.34 \pm 0 \\
.05\end{array}$ & $\begin{array}{l}2.24 * * \pm \\
0.05\end{array}$ & $\begin{array}{l}1.29 \pm 0.0 \\
3\end{array}$ & $\begin{array}{l}2.16^{* *} \pm 0 \\
07\end{array}$ & $\begin{array}{l}1.34 \pm \\
0.01\end{array}$ & $\begin{array}{l}1.57 * \pm 0 \\
07\end{array}$ \\
\hline Wt. gain $(\%)$ & \multicolumn{2}{|c|}{$5.22 \%$} & \multicolumn{2}{|c|}{$70.8 \% * *$} & \multicolumn{2}{|c|}{$62.7 \% * *$} & \multicolumn{2}{|c|}{$17.91 \%$} \\
\hline
\end{tabular}

the body's cellular growth in addition to egg formation.

Effects of supplementation of commercial layer feed on egg Production

The total egg production of the experimental ducks was shown in Table 2. The total egg laying period was about 2.5 months i.e. April to mid-June. It was found that ducks fed $120 \mathrm{~g}$ feed (intensive condition: $\mathrm{T}_{1}$ ) had significantly higher egg production than in other treatments $(\mathrm{P}<0.01)$. Birds with $60 \mathrm{~g}$ feed and scavenging condition $\left(\mathrm{T}_{2}\right)$ attained higher egg production in comparison with $\mathrm{T}_{3}(30 \mathrm{~g}$ feed and scavenging condition) and $\mathrm{T}_{0}$ (fully scavenging without feed supplementation). No significant differences $(\mathrm{P}>0.05)$ were found between $\mathrm{T}_{3}$ and $\mathrm{T}_{0}$ in egg production during the experimental period. Egg production was significantly higher in $T_{1}$ than other treatments, being partially in agreement with Rahman et al.[7] where they found $54.45 \%$ egg production in RIR X Fayoumi(Sonali) during 52 weeks of experimental period in an adlibitum fed group than $36.15 \%$ by $75 \mathrm{~g}$ and $21.37 \%$ by $25 \mathrm{~g}$ supplemented group under scavenging condition. Demeke [8] also found that intensive feeding and scavenging plus $120 \mathrm{~g} / \mathrm{d}$ supplementation gave significantly higher egg production in White Leghorn than the lower level of supplementation (90, 60 and $30 \mathrm{~g} / \mathrm{d}$ ) and concluding that in the scavenging systems egg production is linearly related with the level of supplementation. The effect of $60 \mathrm{~g}$ supplementation in present study was lower than the egg production percentage by $75 \mathrm{~g}$ supplementation

\section{feed on egg weight}

The egg weight of the experimental ducks was shown in Table 2 .It was found that ducks fed $120 \mathrm{~g}$ feed (intensive condition: $\mathrm{T}_{1}$ ) had significantly higher egg weight than in other treatments $(\mathrm{P}<0.01)$. On the other hands it was found that egg weight was significantly lower $(\mathrm{P}<0.01)$ in ducks with no supplementation of feed at scavenging condition $\left(\mathrm{T}_{0}\right)$. No significant difference $(\mathrm{P}>0.05)$ was observed between treatments with feed supplementation and scavenging condition $\left(\mathrm{T}_{2}\right.$ and $T_{3}$ ). The significant difference in egg weight agreed with the results of Rahman et al. [10], but in their study the egg weight in RIR X Fayoumi (Sonali) of different treatment groups (adlibitum, $75 \mathrm{~g}$ supplementation and $25 \mathrm{~g}$ supplementation) were much more higher than the present study.

\section{Effects of supplementation of commercial layer} feed on egg yolk colour

The effect on egg yolk colour of ducks by commercial feed supplementing with daily feed was shown Figure 1. It was found that ducks fed $120 \mathrm{~g}$ feed (intensive condition: $\mathrm{T}_{1}$ ) produced lighter yolk than scavenging birds. Yolk colour was darker in $\mathrm{T}_{0}$. No differences were found in yolk colour between $\mathrm{T}_{2}$ and $\mathrm{T}_{3}$. The colour of the yolk was determined by the presence and absence of xanthophylls some of which are precursor of vitamin A [10]. Therefore the colour of the yolk was influenced to a large degree by nutrition and dark yellow yolks could be produced due to feeding laying birds on grass meal $[11,12]$. The yolk colour score was higher in free range 
system comparing to intensive condition [13, 14]. The darker yellow colour in scavenging birds than in the $T_{1}$ (intensive condition) was due to the access of natural sources of feed supplied to these birds though the diet contained yellow maize in $\mathrm{T}_{1}$

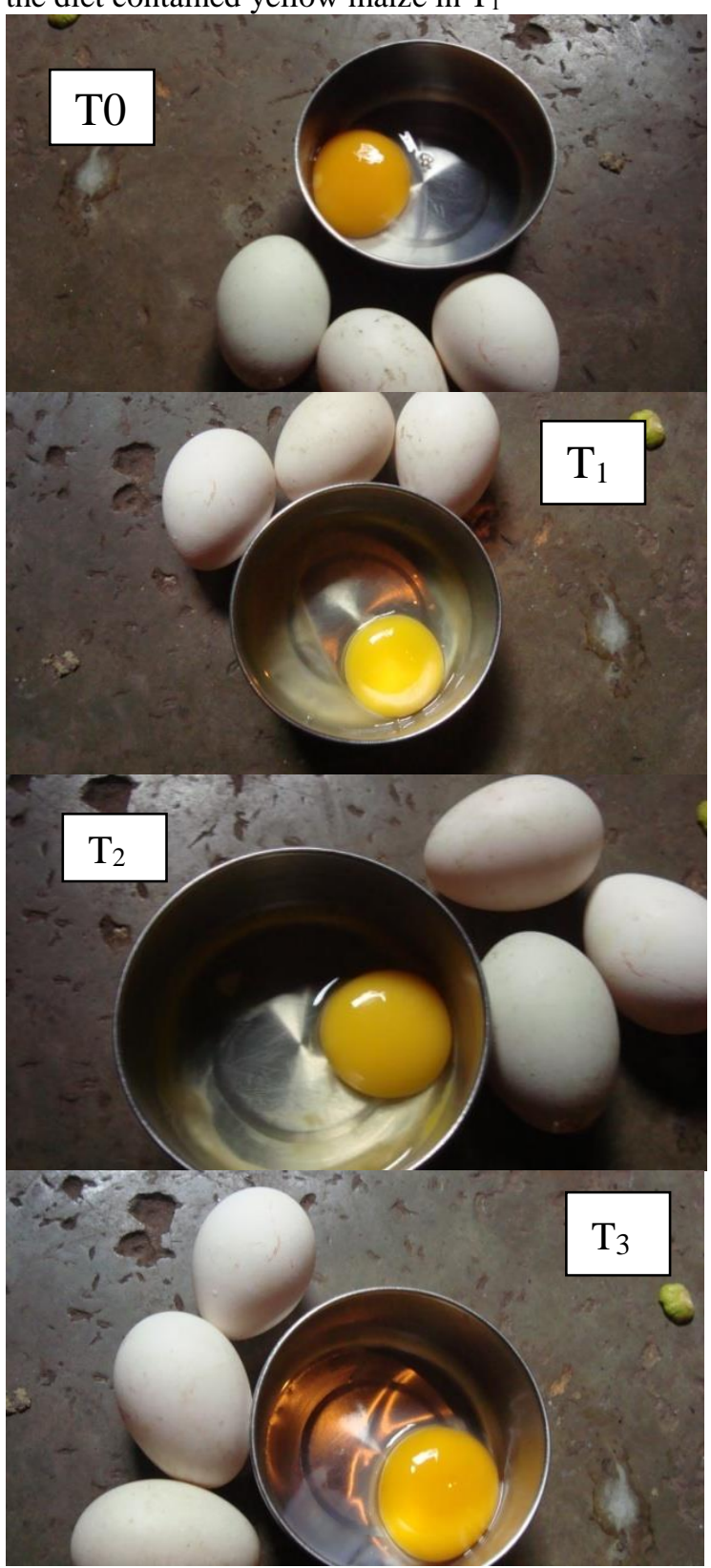

Figure 1 .Differences in the egg yolk color of different groups- $T_{0}, T_{1}, T_{2}$ and $T_{3}$

The hematological parameters were presented in table 3. In this study the post treatment of the mean value of $\mathrm{Hb}$ were $8.08 \mathrm{gm} \%, 7.96 \mathrm{gm} \%, 7.42 \mathrm{gm} \%$ and $7.3 \mathrm{gm} \%$; mean value of PCV were $41.8 \%$, $39.86 \%, 34.85 \%$ and $32.83 \%$; mean value of ESR were $1.38,1.1,0.84$ and $0.68 \mathrm{~mm}$ in first hour; mean value of TEC were $3.79,3.58,3.19$ and 2.94 million/ $\mathrm{mm}^{\text {a }}$ of blood; mean value of TLC were $24.56,22.99,21.62$ and 21.42 thousands $/ \mathrm{mm}^{\mathrm{a}}$; mean value of MCV were $110.41,111.39,110.68$ and $113.6158 \mathrm{fl}$, mean value of $\mathrm{MCH}$ were $21.34,22,24$, 23.50 and $25.30 \mathrm{pg}$; mean value of $\mathrm{MCHC}$ were $19.43,20.00,21.31$ and $22.24 \%$ respectively for the ducks in treatment group $\mathrm{T}_{1}, \mathrm{~T}_{2}, \mathrm{~T}_{3}$ and $\mathrm{T}_{0}$. It was evident that the values of total erythrocyte count (TEC), total leukocyte count (TLC), hemoglobin content $(\mathrm{Hb})$ and packed cell volume (PCV) increased significantly $(\mathrm{P}<0.05)$ in the ducks of $\mathrm{T}_{1}$ and $\mathrm{T}_{2}$ compared to the control group $\left(\mathrm{T}_{0}\right)$ but the value of MCV, MCH and MCHC in the ducks of $\mathrm{T}_{1}$, $\mathrm{T}_{2} \& \mathrm{~T}_{3}$ decreased significantly $(\mathrm{P}<0.05)$ than that of control group. This result partially agree with the findings of Islam et al.[9], who found that the mean value of TEC in intensive chicken was slightly higher but in local chicken slightly lower than intensive chicken. Lowered erythrocyte count were detected at younger birds and increases with the advancement of age in the present study and this findings were was consistent with the findings of Dukes [5]; Kai and Prankin [15]; who reported that erythrocyte number was lower in early age and gradually increases with ages. However, no significant changes were observed in $\mathrm{MCV}, \mathrm{MCH}$ and MCHC in their study.

The recorded ESR in present study was inversely proportional to the age that means higher ESR in early age and decreases gradually as age increases. The recorded maximum values of ESR in $\mathrm{T}_{1}$ group was $2.42 \pm 0.06 \mathrm{~mm}$ in $1^{\text {st }}$ hour at $5^{\text {th }}$ month and the minimum value was $1.38 \pm 0.05 \mathrm{~mm}$ in $1^{\text {st }}$ hour which was found at $8^{\text {th }}$ month of age. Higher ESR at early age in the present study was agreed with the result of Sturkie [16] , Kundu et al. [17] and Levi et al., [18, 19]. Bibert [20], and Sturkie [16] stated that there were many factors responsible for ESR.

\section{Effects on mortality rate}

Among the four treatment groups 1 duck from $\mathrm{T}_{0}$ were died during the experimental period. The tentative causes of mortality were diagnosed by the post mortem examination. One ducks of group $\mathrm{T}_{0}$ was died by chronic respiratory disease (CRD).

\section{CONCLUSION}

The supplementation of commercial layer feed is helpful for improving hematological parameters and reproductive performance of indigenous duck. However, the amount of supplementation is also dependent on location and availability of feed resources around the farmer's house. Better economic condition of farmer and enough feed resources around farmer's house may need less feed supplementation. Further research should conduct to achieve more information among this field for profitable duck farming in the Haor area of Bangladesh.

\section{ACKNOWLEDGEMENT}

The presented study was supported by department of physiology, Faculty of Veterinary and Animal science, Sylhet Agricultural University, Sylhet We are thankful to Upazilla Livestock office, Habigonj sadar and Ajmiriganj, Habigonj and Hore Krishna Diagnostic Centre for their technical assistant and co-operation. 
Table-2. Reproductive performance (Mean \pm SE) of different treatments group during the experimental period $(n=5)$

\begin{tabular}{|c|c|c|c|c|c|c|c|c|}
\hline \multirow[t]{2}{*}{ Parameters } & \multicolumn{2}{|c|}{ GroupTo } & \multicolumn{2}{|c|}{ Group $_{1}$} & \multicolumn{2}{|c|}{ Group $_{2}$} & \multicolumn{2}{|c|}{ GroupT $_{3}$} \\
\hline & $\begin{array}{l}\text { Mea } \\
n \pm S \\
E\end{array}$ & $\begin{array}{l}\text { Pvalu } \\
\text { e } \\
(p>t)\end{array}$ & Mean \pm SE & $\begin{array}{l}\text { Pvalue } \\
(p>t)\end{array}$ & Mean \pm SE & $\begin{array}{l}\text { Pvalue } \\
(p>t)\end{array}$ & $\begin{array}{l}\text { Mean } \pm S \\
\text { E }\end{array}$ & $\begin{array}{l}\text { Pvalue } \\
(p>t)\end{array}$ \\
\hline $\begin{array}{l}\text { Egg production } \\
\text { during } \\
\text { experimental } \\
\text { period (no.) }\end{array}$ & $\begin{array}{l}65.8 \\
\pm 2 \\
6\end{array}$ & 0.00 & $\begin{array}{l}85.4 * * \pm 1 . \\
4\end{array}$ & 0.000 & $\begin{array}{l}83.2 * * \pm 1 . \\
5\end{array}$ & 0.000 & $69.4 \pm 2.6$ & $\begin{array}{l}0.18126 \\
5\end{array}$ \\
\hline Egg weight (gm) & $\begin{array}{l}64.2 \\
\pm .7 \\
3\end{array}$ & 0.00 & $\begin{array}{l}73.4^{* *} \pm 0 \\
68\end{array}$ & 0.000 & $\begin{array}{l}71.8 * * \pm 0 . \\
80\end{array}$ & 0.000 & $68 * \pm 1.0$ & $\begin{array}{l}0.01016 \\
7\end{array}$ \\
\hline $\begin{array}{l}\% \text { of egg } \\
\text { production }\end{array}$ & \multicolumn{2}{|c|}{$73.1 \%$} & \multicolumn{2}{|c|}{$94.8 \%$} & \multicolumn{2}{|c|}{$92.4 \%$} & \multicolumn{2}{|c|}{$77.1 \%$} \\
\hline Egg yolk colour & \multicolumn{2}{|c|}{$\begin{array}{l}\text { Dark yellow } \\
\qquad(++++)\end{array}$} & \multicolumn{2}{|c|}{$\begin{array}{l}\text { Light yellow } \\
(+)\end{array}$} & \multicolumn{2}{|c|}{$\begin{array}{l}\text { Light yellow } \\
\qquad(++)\end{array}$} & \multicolumn{2}{|c|}{$\begin{array}{r}\text { Dark yellow } \\
(+++)\end{array}$} \\
\hline
\end{tabular}

Table 3.Effects of supplementation of commercial layer feed on hematological paramaters (Mean \pm SE) in the experimental ducks $(\mathrm{n}=5)$

\begin{tabular}{|c|c|c|c|c|c|c|c|c|}
\hline \multirow[t]{2}{*}{ Parameters } & \multicolumn{2}{|c|}{ Group $_{0}$} & \multicolumn{2}{|c|}{ Group $_{1}$} & \multicolumn{2}{|c|}{ Group $_{2}$} & \multicolumn{2}{|c|}{ GroupT $_{3}$} \\
\hline & Mean \pm SE & $\begin{array}{l}\text { Pvalu } \\
\mathrm{e} \\
(\mathrm{P}>\mathrm{t})\end{array}$ & Mean \pm SE & $\begin{array}{l}\text { Pvalu } \\
\text { e } \\
(P>t)\end{array}$ & Mean \pm SE & $\begin{array}{l}\text { Pvalue } \\
(P>t)\end{array}$ & $\begin{array}{l}\text { Mean } \pm S \\
\text { E }\end{array}$ & $\begin{array}{l}\text { Pvalue } \\
(P>t)\end{array}$ \\
\hline $\mathrm{Hb}(\mathrm{gm} \%)$ & $7.3 \pm 0.04$ & 0.00 & $\begin{array}{l}8.08 * * \pm 0.0 \\
7\end{array}$ & 0.000 & $\begin{array}{l}7.96 * * \pm 0 . \\
14\end{array}$ & 0.003 & $\begin{array}{l}7.42 * \pm 0 \\
07\end{array}$ & $\begin{array}{l}0.10771 \\
4\end{array}$ \\
\hline $\operatorname{PCV}(\%)$ & $32.8 \pm 0.40$ & 0.00 & $41.8 * * \pm 1.4$ & 0.001 & $\begin{array}{l}39.8 * * \pm 1 \\
05\end{array}$ & 0.000 & $\begin{array}{l}34.8 * \pm 0 \\
71\end{array}$ & $\begin{array}{l}0.02321 \\
2\end{array}$ \\
\hline $\begin{array}{l}\text { ESR ( } \mathrm{mm} \text { in } \\
\left.1^{\text {st }} \mathrm{hr}\right)\end{array}$ & $0.68 \pm 0.08$ & 0.000 & $\begin{array}{l}1.38 * * \pm 0.0 \\
5\end{array}$ & 0.000 & $\begin{array}{l}1.1 * * \pm 0.0 \\
3\end{array}$ & 0.002 & $\begin{array}{l}0.84 * \pm .1 \\
2\end{array}$ & $\begin{array}{l}0.15769 \\
9\end{array}$ \\
\hline $\begin{array}{l}\text { TEC } \\
\text { (million/cu.m } \\
\text { m. of blood) }\end{array}$ & $2.94 \pm 0.19$ & 0.000 & $\begin{array}{l}3.79 * * \pm 0.0 \\
3\end{array}$ & 0.005 & $\begin{array}{l}3.58 * \pm 0.0 \\
4\end{array}$ & 0.014 & $\begin{array}{l}3.19 \pm 0.1 \\
7\end{array}$ & $\begin{array}{l}0.18181 \\
8\end{array}$ \\
\hline $\begin{array}{l}\text { TLC } \\
\text { (thousand/cu. } \\
\text { mm. of } \\
\text { blood) }\end{array}$ & $21.42 \pm 0.3$ & 0.000 & $24.56 * \pm 1.2$ & 0.03 & $\begin{array}{l}22.99 * \pm 0 . \\
44\end{array}$ & 0.011 & $\begin{array}{l}21.62 \pm 0 . \\
88\end{array}$ & $\begin{array}{l}0.41939 \\
8\end{array}$ \\
\hline $\operatorname{MCV}(\mathrm{fl})$ & $\begin{array}{l}113.61 \pm 7 . \\
5\end{array}$ & 0.000 & $110.41 \pm 4.1$ & 0.364 & $\begin{array}{l}111.39 \pm 3 . \\
1\end{array}$ & $\begin{array}{l}0.3979 \\
66\end{array}$ & $\begin{array}{l}110.39 \pm 7 \\
.0\end{array}$ & $\begin{array}{l}0.39129 \\
9\end{array}$ \\
\hline $\mathrm{MCH}(\mathrm{pg})$ & $25.30 \pm 1.8$ & 0.000 & $21.34 \pm 0.20$ & 0.046 & $\begin{array}{l}22.24 \pm 0.3 \\
9\end{array}$ & $\begin{array}{l}0.0825 \\
77\end{array}$ & $\begin{array}{l}23.50 \pm 1 \\
19\end{array}$ & $\begin{array}{l}0.21641 \\
2\end{array}$ \\
\hline $\mathrm{MCHC}(\%)$ & $\begin{array}{l}22.24 \pm 0.2 \\
4\end{array}$ & 0.000 & $19.43 \pm 0.66$ & 0.005 & $20.0 \pm 0.39$ & $\begin{array}{l}0.0011 \\
39\end{array}$ & $\begin{array}{l}21.31 \pm 0 . \\
38\end{array}$ & 0.03991 \\
\hline
\end{tabular}

\footnotetext{
* Significant $(\mathrm{P}<0.05)$

** Significant $(\mathrm{P}<0.01)$

$\mathrm{SE}=$ Standard Error
} 


\section{REFERENCES}

1. DLS. 2007. Annual Progress Report. Department of Livestock Services. Farm gate, Dhaka.

2. BBS. 2007. Bangladesh Bureau of Statistics. Statistical Year book of Bangladesh. Ministry of Planning, Government of the People's Republic of Bangladesh, Dhaka. pp. 33-34.

3. Alam J 1995. Livestock resources in Bangladesh present status and futures potential. Agricultural University Press Ltd. pp. 12-29.

4. Prasad S., C.K Aggarwal and S.K Chopra (1998).Effect of restricted time feeding during summer on hemoglobin, packed cell volume, calcium and phosphorus levels in blood of pullets. Indian Journal of Poultry Science.33(3). 210-213

5. Dukes H.H. (1955).The Physiology of Domestic Animals. Seventh edition. Comstock publishing Inc.USA.

6. $\quad$ 6. Lamberg S.L. and R. Rothstein (1977). Laboratory Manual of Hematology and Urinalysis. 2nd edn., Avi. Publishing. Company, Inc, West Port Connecticut, USSR.

7. Rahman M., M. N.Islam, N. R.Sarkerand M. M.Islam (1998).Effect of supplementary feeding on production performance of RIR, Fayoumi and their crossbred chicken in rural Bangladesh. Bangladesh Journal of Livestock research, 1:184-193.

8. Demeke S. (1996). Study on egg production of White Leghorn under intensive, semiintensive and rural household conditions in Ethiopia. Livestock Research for Rural Development, 8: 89-92.

9. Islam M.K., N. Ahmed, M.A. Islam, A. Sha and P.K. Roy (1999).Effect of ostectomy on body weight and certain hematological parameters in chickens.The Bangladesh Veterinary journal. 33(1-2):55-59.

10. Rahman M., P.Sorensen, H.A. Jensen and F.Dolberg (1997). Exotic hens under semi scavenging condition in Bangladesh,
Livestock Research for Rural Development, 9:

http://www.hcm.fpt.vn/inet/ 1rrd/lrrd9/3/ba ng931.htm

11. Smith A. J. (1996). Poultry PoultryTropical Agriculturist Series .Macmillan Education Ltd, London and Oxford.pp.130.

12. Taplin D. E., J. P. F. D'Mello, and P.Phillips (1983).Evaluation of Leucaena leaf meal from Ma-lawi as a source of xanthophylls for the laying hen.Tropical Science, 23: 217-226.

13. Pavlovski Z., Masic B., Apolostov N. (1981). Quality of eggs laid by hens on free range and in cages. In: Quality of Eggs, Proceedings of the First European Symposium (Beuving G,Sheele C.W. and Simons P.C.M. eds), pp 231-235 Apeldoom, The Netherlands.

14. Pavloski Z., Hopic S., Vracar S., Masic B. (1994). The effects of housing system of internal egg quality traits in small layer flocks. Biotechnologija Stocarstvu, 10: 3743

15. Kai O and R.M. Pranklin (1984).The age dependent size distribution chicked blood cell analyzed by a novel method utilizing a coulter conter.Development and comparative Immunology 8:375-386.

16. Sturkie, P.D., 1954. Avian Physiology. $2^{\text {nd }}$ Edition, pp: 58. Comstock Publishing, Ithaca, New York.

17. KunduA.k., B.P.Mohanty, S.C. Mishra and M.S. Mishra (1993). Age related changes in the hematology of guinea fowls. Indian Journal of Poultry Science. 28:200-207.

18. Levi A., B. Perelman, T. Waner, M. Grevenbrock, C.V. Vancreveld and R. Yagil (1989).Hematological parameters of the ostrich. Avian pathology.18:321:327.

19. Coffin D.L.(1955).Manual of veterinary clinical Pathology. Third edition.Comstack Publishing Company.Inc, Ithaca, New York.

20. Bibert B.A. (1962). Sedimentation rate of erythrocytes in the Domesticated cocks. Poultry Sciience.41:784-788. 